\title{
RESEARCH
}

Open Access

\section{Effects of the myrtle essential oil on the acne skin-clinical trials for Korean women}

\author{
Kyung Yun Kim ${ }^{1}$, Hyun Hee Jang ${ }^{2}$, Sung Nae Lee ${ }^{3}$, Young-Sam Kim ${ }^{4}$ and Sungkwan $\mathrm{An}^{5^{*}}$ (D)
}

\begin{abstract}
Background: This study aims to clinically verify the effects of myrtle essential oil, which has non-irritation, nontoxicity, and non-sensitivity characteristics among natural materials, by applying the oil to acne skin of Korean women, with special emphasis on a development of natural substances with a high safety to relieve acne and minimize skin irritation.
\end{abstract}

Methods: After a homogeneity test was conducted targeting 20 Korean women with acne skin, who have met the primary and the secondary clinical selection criteria, the subjects were divided into the treatment group with myrtle essential oil applied (the experimental group) and the no-treatment group with no myrtle essential oil applied (the control group) to use provided cosmetics every morning and evening for 6 weeks. To precisely check the effects of the myrtle substances, the provided cosmetics are made with only a difference in the presence or absence of added myrtle substances, leaving all other substances equal.

Results: The acne grades significantly decreased in the experimental group with myrtle applied, with the pore index (outstanding pores, large pores, blackheads), the erythema index, the sebum index, and the desquamation index also decreased in the group. Lastly, the microorganism index decreased considerably in the experimental group, showing all evaluation indicators related to acne improved in the experimental group in a statistically significant manner. On the other hand, the acne grades a little decreased in the control group with no myrtle applied, but with no statistical significance, while the pore index (outstanding pores, large pores, blackheads), the erythema index, the sebum index, and the desquamation index rather increased to some extent. In addition, the microorganism index decreased in the control group, but with a smaller volume of changes than that in the experimental group.

Conclusion: This study has clinically proved that myrtle essential oil has effects for convergence, reduction in erythema, removal of sebum and dead skin cells, and antibacterial activity on the facial skin of Korean women. Especially, this study confirmed that myrtle essential oil is a safe, skin-soothing substance effective for treating acne by showing the oil reduced the number of erythema.

Trial registration: -Name of the registry: Institutional Review Board of Korea Institute of Dermatological Sciences -Trial registration number 1-70005239-AB-N-01-2018-KIDS-AHA043-HR-01

-Date of registration: March 2, 2018.

Keywords: Myrtle, Acne, Pores, Erythema, Sebum, Dead skin cells, Antibacterial

\footnotetext{
* Correspondence: ansungkwan@konkuk.ac.kr

${ }^{5}$ Department of Cosmetics Engineering, Konkuk University, 120

Neungdong-ro, Gwangjin-gu, Seoul 05029, Republic of Korea

Full list of author information is available at the end of the article
}

(C) The Author(s). 2018 Open Access This article is distributed under the terms of the Creative Commons Attribution 4.0 International License (http://creativecommons.org/licenses/by/4.0/), which permits unrestricted use, distribution, and

reproduction in any medium, provided you give appropriate credit to the original author(s) and the source, provide a link to the Creative Commons license, and indicate if changes were made. The Creative Commons Public Domain Dedication waiver (http://creativecommons.org/publicdomain/zero/1.0/) applies to the data made available in this article, unless otherwise stated. 


\section{Background}

Acne is made by a combination of an increased sebum in follicles, hyperkeratinization of dead skin cells, proliferation of $P$. acne, inflammatory reaction, etc. (Sandoval et al. 2014). Treatment substances currently applied to acne show rapid effects, but still many issues are being reported, including erythema, occurrence of resistant strains due to antibiotics, teratogenicity, pruritus, pyrosis, and hormonal side effects (Khunger et al. 2008). To settle those issues, therapies are being presented for acne using glycyrrhizic acid, ginnarin, astemisic acid, berberine, hesperidin, etc., which are obtained from natural materials (Momin et al. 2010; Del Rosso et al. 2016; Boni and Nehrhoff 2003). Among various natural substances, essential oil has been used as attractive materials for cosmetics in the American and European markets over the past decades, having also been used for home remedy across the world already for centuries (Yang et al. 2004). Myrtle essential oil has been used for treating acne, oily skin, and loose pores especially around the Mediterranean even from the Middle Ages (Li et al. 2018; Battaglia 1997), being known as a soft, mild sort of oil with effects for reproduction, convergence, and prevention of allergy (Aleksic and Knezevic 2014). Myrtle essential oil comprises $35.9 \%$ of myrtenyl acetate, an ester substance; $29.89 \%$ of 1,8-cineole, an oxide substance; and $8.18 \%$ of $\alpha$-pinene and $7.58 \%$ of limonene, which are mono terpene substances (Battaglia 1997). These ester, oxide, and mono terpene-based substances present effects for convergence, soothing, prevention of germs, and reduction of dead skin cells (Ghasemi et al. 2011; Battaglia 1997). Especially, while most substances with effects for reduction of dead skin cells and sebum and prevention of germs make the human skin more sensitive, myrtle, thanks to its $36 \%$ of ester substances, is reported to treat acne even without irritating the skin (Battaglia 1997). There is also a great deal of other literature on the effects and applications of myrtle, but any data verifying those effects directly through a clinical test have not been found anywhere. Accordingly, this study aims to examine the impacts of myrtle essential oil on Koreans' acne skin and to reveal its possibility to be used for cosmetics for acne skin with a high safety, which minimizes irritation to the skin without causing allergic reactions.

\section{Methods}

\section{Subjects and study design}

From among Korean women with acne on their facial skin, this study selected 20 subjects meeting the clinical selection criteria, excluding those who are not appropriate for the clinical test through a primary survey. The selection criteria are as follows:

- Those who have neither atopy nor chronic skin disease;

- Those who are not having their acne treated currently;

- Those who have not had their facial skin peeled over the past 6 months;

- Those who have not received skin scaling, laser treatment, acne treatment, or skin care for acne skin to treat acne over the past 1 month;

- Those who have not taken a medicine which may affect the hormonal system over the past 1 month;

- Those who have not used any acne treatment medicine or cosmetics including AHA, salicylic acid, and sulfa over the past 1 month;

- Those who do not have any allergy to cosmetics; and,

- Those who have understood the objective of this study and have given their consent to take part in the study.

By conducting a homogeneity test for each of the Korean Acne Grading System (KAGS), the erythema index, the pore index, the sebum index, the desquamation index, and the microorganism index, this study selected 10 persons for the experimental group and 10 other persons for the control group, who are statistically equal, as the final subjects for the tests. This study conducted three sessions of self-skin care training and the clinical test for 6 weeks from 5 March to 16 April 2018. The subjects were informed about all information with regard to the test and took part in the test after signing a written consent according to their will. In addition, all clinical tests for this study have undergone the deliberation of the Institutional Review Boards before starting the tests (NO. 1-70005239-AB-N-01-2018-KIDS-AHA043-HR-01).

\section{Test method}

The control group was used a foam cleanser, toner, emulsion, and sunblock of a cosmetics company with the initial of $R$ every day, any of which does not contain myrtle substances, and a cream pack once a week, as a skin care on their own. The control group received a salon treatment once a week, which includes the steps of pressing out acne; applying an algae mask with no myrtle substances for $15 \mathrm{~min}$; and applying a toner, emulsion, and sunblock made by the cosmetics company $\mathrm{R}$, which do not contain any myrtle substances. On the other hand, the experimental group was let use a foam cleanser, toner, emulsion, and sunblock made by the cosmetics company $\mathrm{R}$ every day, all of which contain myrtle substances, and a cream pack containing myrtle 
substances once a week, as a skin care on their own. The experimental group also received a salon treatment once a week, which includes the steps of pressing out acne; applying an algae mask with myrtle substances for $15 \mathrm{~min}$; and applying a toner, emulsion, and sunblock made by the cosmetics company $\mathrm{R}$, all of which contain myrtle substances.

\section{Measurement method \\ Measurement of changes by KAGS}

The Korean Acne Grading System (KAGS) is an evaluation system reflecting the characteristics of acne on the skin of Koreans, which classifies the severity of acne into six grades, reflecting the dynamic clinical features of Koreans' facial skin (Table 1). The KAGS present the reference photographs of Koreans for each grade and the scope-type criteria for reference lesions, thereby seeking application convenience, clarity, and objectivity in Koreans to be available for determination of treatment effects. According to the KAGS criteria, this study observed and compared the changes in severity in the control group and the experimental group, and determined the acne grades of the subjects for this study before, 3 weeks after, and 6 weeks after using the provided cosmetics products.

\section{Measuring devices}

To measure the erythema index (EI) of the acne skin, this study used the Mexameter MX18 (Courage and Kazaka Electronic, Germany). To measure the pore index, this study filmed the pore condition of the subjects' faces by using the RSA (Robo skin analyzer CS50, Japan) and analyzed the pore index by using a program attached to the RSA. To measure the sebum index, this study attached a measuring tape with the same pressure, detached the tape after the same period of time, and measured the quantity of sebum by using an oil and moisture measuring device (Skin diagono system, Bomtech, Korea). To measure the desquamation index (DI) of the surface of the skin, this study attached a measuring tape with the same pressure, detached the tape after the same period of time, and figured out the

Table 1 Korean acne grading system

\begin{tabular}{ll}
\hline Grade & Description \\
\hline 1 & Papules $^{\mathrm{a}} \leq 10$ \\
2 & Papules $11-30$ \\
3 & Papules $\geq 31$, nodules $^{\mathrm{b}} \leq 10$ \\
4 & Nodules $11-20, \pm$ mild ongoing scars \\
5 & Nodules $21-30, \pm$ moderate ongoing scars \\
6 & Nodules $\geq 31, \pm$ severe ongoing scars, \pm sinus tract \\
\hline aPapule, acne which is smaller than $5 \mathrm{~mm}$ \\
${ }^{\mathrm{b}}$ Nodule, acne which is larger than $5 \mathrm{~mm}$
\end{tabular}

desquamation index based on the number of dead skin cells fallen off from the surface of the skin by using the Skin-Visiometer SV600 (CCD camera type-Visioscan). To measure the quantity of microorganisms on the surface of the skin, this study rubbed the forehead, chin, and both cheeks of the subjects with a disposable cotton swab named LuciPac $\mathrm{W}^{\circ}$ seven times for each part, put the end of the cotton swabs in a solution, shook around 10 times, and then measured the relative light unit (RLU) by using the Lumitester TM PD-10 (KIKOMAN, Japan). You can check the presence or absence of microorganisms in accordance with the RLU.

\section{Conditions and parts for measurement}

The subjects washed their faces by using the same cleanser, took rest for $30 \mathrm{~min}$ (the erythema index, the pore index), $40 \mathrm{~min}$ (the sebum index), and $50 \mathrm{~min}$ (the desquamation index) under the conditions of constant temperature and humidity $\left(22-24{ }^{\circ} \mathrm{C}\right.$ of temperatures, $40-60 \%$ of relative humidity), and then had their skin condition measured before, 3 weeks after, and 6 weeks after using the provided products. The measurement was conducted four times with the same posture at the same time zone in the same place under the same lightings. Then, the averages and standard deviations of the measurements were recorded.

The measured parts were the forehead, both cheeks, and the chin. Of the forehead measured was the central point between two acupuncture points of "Shinjung" and "Indang." In the chin, the acupuncture point named "Seungjang" under the lower lip was measured. In both cheeks, the parts vertically down from the center of the pupils, being horizontal with the end of the nose, were the measured points. The average measurements were calculated for the forehead, cheeks, and chin, being used for figuring out the erythema index, the sebum index, and the desquamation index for the entire face.

\section{Test materials}

The myrtle essential oil for the test is extracted by a steam distillation method. This study made and used the foam cleanser, toner, emulsion, and cream pack for the test by the below methods.

\section{Foam cleanser}

Phase A was dissolved at $65-70^{\circ} \mathrm{C}$, with phase B dissolved at $70-75^{\circ} \mathrm{C}$. Then, cocamidopropyl betaine was put into phase $\mathrm{B}$ at a room temperature to dissolve. After that, both phases A and B were saponified at 70$75^{\circ} \mathrm{C}$ by a homo mixer at $3500 \mathrm{rpm}$ and a paddle mixer at $20 \mathrm{rpm}$ for $10 \mathrm{~min}$. Cocamidopropyl betaine was put into the saponified phases A and B to mix them by a homo mixer at $3500 \mathrm{rpm}$ and a paddle mixer at $20 \mathrm{rpm}$ for $3 \mathrm{~min}$. The mixture was cooled down to $30^{\circ} \mathrm{C}$, and 
Myrtus communis extract was finally added only to the cosmetics for the experimental group (Table 2).

\section{Toner}

Phase A was dissolved at $45-48{ }^{\circ} \mathrm{C}$, with phase B dispersed for $30 \mathrm{~min}$. They were agitated by a homo mixer at $2000 \mathrm{rpm}$ and a paddle mixer at $25 \mathrm{rpm}$ at $45-48^{\circ} \mathrm{C}$ for $10 \mathrm{~min}$. During the agitation process, phase $\mathrm{C}$, which had been dissolved at $45-48^{\circ} \mathrm{C}$, was added. After that, Myrtus communis extract was added only to the cosmetics for the experimental group. Phase D was dispersed at a room temperature. Then, phases A, B, and $C$, which had been mixed with each other, were agitated by a homo mixer at $2500 \mathrm{rpm}$ and a paddle mixer at 25 rpm at $45-48^{\circ} \mathrm{C}$ for $5 \mathrm{~min}$. Phase $\mathrm{D}$ was added to the mixture during the agitation process. After the agitation, the mixture was cooled down to $28^{\circ} \mathrm{C}$ to be filtered and discharged (Table 3).

\section{Emulsion}

Phase A was dissolved at $75-78^{\circ} \mathrm{C}$, with phases $\mathrm{B}$ and $\mathrm{C}$ dispersed for $30 \mathrm{~min}$. Then, phases $B$ and $C$ were put into phase A to be mixed with each other. After that,

Table 2 Formulations of cleansing form ingredients

\begin{tabular}{|c|c|c|}
\hline \multirow[t]{2}{*}{ Ingredients } & \multicolumn{2}{|c|}{ Compositions (wt\%) } \\
\hline & Control & Myrtle \\
\hline \multicolumn{3}{|l|}{ Phase A } \\
\hline Water & q.s to 100 & q.s to 100 \\
\hline Glycerin & 6.00 & 6.00 \\
\hline Propylene glycol & 5.00 & 5.00 \\
\hline PEG-8 & 2.00 & 2.00 \\
\hline Methylparaben & 0.20 & 0.20 \\
\hline Tetrasodium EDTA & 0.05 & 0.05 \\
\hline Potassium hydroxide & 5.00 & 5.00 \\
\hline Cocamidopropyl betaine & 0.50 & 0.50 \\
\hline \multicolumn{3}{|l|}{ Phase B } \\
\hline Stearic acid & 5.00 & 5.00 \\
\hline Myristic acid & 20.00 & 20.00 \\
\hline Lauric acid & 5.00 & 5.00 \\
\hline Beeswax & 1.00 & 1.00 \\
\hline Glycol stearate & 2.00 & 2.00 \\
\hline Propylparaben & 0.10 & 0.10 \\
\hline Hydrogenated polydecene & 1.00 & 1.00 \\
\hline Glyceryl stearate, PEG-100 stearate & 2.50 & 2.50 \\
\hline Cetearyl alcohol & 0.50 & 0.50 \\
\hline PEG-40 hydrogenated castor oil & 0.80 & 0.80 \\
\hline \multicolumn{3}{|l|}{ Phase C } \\
\hline Sodium methyl cocoyl taurate & 2.00 & 2.00 \\
\hline Myrtus communis extract & - & 0.50 \\
\hline
\end{tabular}

Table 3 Formulations of toner ingredients

\begin{tabular}{lll}
\hline Ingredients & \multicolumn{2}{l}{ Compositions (wt\%) } \\
\cline { 2 - 3 } & Control & Myrtle \\
\hline Phase A & q.s to 100 & q.s to 100 \\
Water & 0.03 & 0.03 \\
Trisodium EDTA & 0.70 & 0.70 \\
Betaine & 3.50 & 3.50 \\
Sodium hyaluronate & 6.00 & 6.00 \\
Glycerin & 6.00 & 6.00 \\
Dipropylene glycol & & \\
Phase B & 12.00 & 12.00 \\
Water & 0.12 & 0.12 \\
Acrylates/C10-30 alkyl acrylate crosspolymer & & \\
Phase C & 1.00 & 1.00 \\
SD alcohol 40-B & 0.10 & 0.10 \\
Ehylparaben & 0.20 & 0.20 \\
Methylparaben & 1.50 & 1.50 \\
Triethylhexanoin & 2.00 & 2.00 \\
Pentaerythrityl-tetraethylhexanoate & - & 0.50 \\
Myrtus communis extract & & \\
Phase D & 1.00 & 1.00 \\
Water & 0.20 & 0.20 \\
Triethanolamine & & \\
\hline & & \\
\hline
\end{tabular}

phase $\mathrm{D}$ was dissolved at $75-78^{\circ} \mathrm{C}$, adding cyclopentasiloxane in the middle of the process to be mixed with each other. The mixed phases A, B, C, and D were agitated by a homo mixer at $3500 \mathrm{rpm}$ and a paddle mixer at $25 \mathrm{rpm}$ at $75-78{ }^{\circ} \mathrm{C}$ for $5 \mathrm{~min}$. When the agitation is almost finished, water and trethanolamine were put into the mixture. Myrtus communis extract was put into the cosmetics for the experimental group, to be agitated by a homo mixer at $3500 \mathrm{rpm}$ and a paddle mixer at $25 \mathrm{rpm}$ at a room temperature for $2 \mathrm{~min}$ (Table 4).

\section{Cream pack}

Phase A was dissolved at $75-78{ }^{\circ} \mathrm{C}$. Phases $\mathrm{B}$ and $\mathrm{C}$, which are aqueous carbomer solution dispersed for 30 min, were put into phase A to be agitated by a homo mixer at $3500 \mathrm{rpm}$ and a paddle mixer at $24 \mathrm{rpm}$ at $75-$ $78^{\circ} \mathrm{C}$ for $5 \mathrm{~min}$. Phase $\mathrm{D}$ was dissolved at $75-78^{\circ} \mathrm{C}$, adding cyclopentasiloxane to that in the middle of the process. The mixed phases A, B, C, and D were agitated by a homo mixer at $3500 \mathrm{rpm}$ and a paddle mixer at 25 $\mathrm{rpm}$ at $75-78^{\circ} \mathrm{C}$ for $5 \mathrm{~min}$. Water and triethanolamine were dispersed at a room temperature to be mixed with the agitated phases A, B, C, and D. The whole mixture was agitated by a homo mixer at $3500 \mathrm{rpm}$ and a paddle mixer at $25 \mathrm{rpm}$ at $40-45^{\circ} \mathrm{C}$ for $2 \mathrm{~min}$. Myrtus 
Table 4 Formulations of emulsion ingredients

\begin{tabular}{|c|c|c|}
\hline \multirow[t]{2}{*}{ Ingredients } & \multicolumn{2}{|c|}{ Compositions (wt\%) } \\
\hline & Control & Myrtle \\
\hline \multicolumn{3}{|l|}{ Phase A } \\
\hline Water & q.s to 100 & q.s to 100 \\
\hline Trisodium EDTA & 0.012 & 0.012 \\
\hline Methylparaben & 0.20 & 0.20 \\
\hline Betaine & 0.50 & 0.50 \\
\hline Panthenol & 0.70 & 0.70 \\
\hline Glycerin & 8.00 & 8.00 \\
\hline Dipropylene glycol & 10.00 & 10.00 \\
\hline \multicolumn{3}{|l|}{ Phase B } \\
\hline Water & 10.00 & 10.00 \\
\hline Xanthan gum & 0.10 & 0.10 \\
\hline \multicolumn{3}{|l|}{ Phase C } \\
\hline Water & 10.00 & 10.00 \\
\hline Carbomer & 0.10 & 0.10 \\
\hline \multicolumn{3}{|l|}{ Phase D } \\
\hline Cetearyl alcohol & 1.50 & 1.50 \\
\hline Glyceryl stearate & 1.00 & 1.00 \\
\hline Glyceryl stearate, PEG-100 stearate & 1.00 & 1.00 \\
\hline Ehylparaben & 0.10 & 0.10 \\
\hline Propylparaben & 0.10 & 0.10 \\
\hline Macadamia ternifolia seed oil & 2.00 & 2.00 \\
\hline Phytosteryl/isostearyl/cetyl/stearyl/behenyl dimer dilinoleate & 0.10 & 0.10 \\
\hline Hydrogenated polydecene & 2.00 & 2.00 \\
\hline Neopentyl glycol dicaprate & 1.00 & 1.00 \\
\hline Dimethicone & 0.30 & 0.30 \\
\hline Cyclopentasiloxane & 1.00 & 1.00 \\
\hline Water & 1.00 & 1.00 \\
\hline Triethanolamine & 0.14 & 0.14 \\
\hline Myrtus communis extract & - & 0.50 \\
\hline
\end{tabular}

communis extract was added only to the cosmetics for the experimental group (Table 5).

\section{Statistical analysis}

This study analyzed the statistical data by using the SPSS 12.0, and the characteristics of the subjects were analyzed through a frequency analysis. To examine the differences in effects between the group treated with myrtle and the no-treatment group conducted were the $t$ test and the one-way ANOVA.

\section{Results}

\section{Homogeneity test}

Acne grades of subjects

In terms of the acne grades, the experimental group consisted of five persons with grade 1 (50\%), three persons with grade 2 (30\%), one person with grade 3 (10\%), and one person with grade $4(10 \%)$. The control group consisted of six persons with grade 1 (60\%), two persons with grade 2 (20\%), and two persons with grade 3 (20\%). Since there was no statistically significant difference between the two groups, it can be said that this study secured the homogeneity between subjects in acne determination (Table 6).

\section{Skin condition of subjects}

To evaluate the skin condition of the subjects, this study measured the erythema index, the number of outstanding pores, the number of large pores, blackheads, the sebum index, the desquamation index, and the microorganism index, but no statistically significant difference was found. Accordingly, it was learned that this study 
Table 5 Formulations of cream pack ingredient

\begin{tabular}{|c|c|c|}
\hline \multirow[t]{2}{*}{ Ingredient } & \multicolumn{2}{|c|}{ Composition (wt\%) } \\
\hline & Control & Myrtle \\
\hline \multicolumn{3}{|l|}{ Phase A } \\
\hline Water & q.s to 100 & q.s to 100 \\
\hline Trisodium EDTA & 0.10 & 0.10 \\
\hline Methylparaben & 0.20 & 0.20 \\
\hline 1,2-Hexanediol & 1.00 & 1.00 \\
\hline Glycerin & 8.00 & 8.00 \\
\hline \multicolumn{3}{|l|}{ Phase B } \\
\hline Water & 10.00 & 10.00 \\
\hline Carbomer & 0.15 & 0.15 \\
\hline \multicolumn{3}{|l|}{ Phase C } \\
\hline Butylene glycol & 8.00 & 8.00 \\
\hline Sodium polyacrylate & 0.25 & 0.25 \\
\hline Water & 20.00 & 20.00 \\
\hline \multicolumn{3}{|l|}{ Phase D } \\
\hline C14-22 alcohols, C12-20 alkyl glucoside & 1.00 & 1.00 \\
\hline Glyceryl stearate SE & 1.00 & 1.00 \\
\hline Cetearyl alcohol & 1.00 & 1.00 \\
\hline Glyceryl stearate, PEG-100 stearate & 1.00 & 1.00 \\
\hline Butyrospermum parkii (shea butter) & 1.00 & 1.00 \\
\hline Triethylhexanoin & 2.00 & 2.00 \\
\hline Hydrogenated polydecene & 5.00 & 5.00 \\
\hline Caprylic/capric triglyceride & 5.00 & 5.00 \\
\hline Propylparaben & 0.05 & 0.05 \\
\hline Ehylparaben & 0.10 & 0.10 \\
\hline Sorbitan stearate & 0.50 & 0.50 \\
\hline PEG-40 stearate & 0.50 & 0.50 \\
\hline Dimethicone & 0.40 & 0.40 \\
\hline Cyclopentasiloxane & 1.00 & 1.00 \\
\hline Water & 1.00 & 1.00 \\
\hline Triethanolamine & 1.00 & 1.00 \\
\hline Myrtus communis extract & - & 0.5 \\
\hline
\end{tabular}

Table 6 Test of homogeneity for Korean acne grading index

\begin{tabular}{lllll}
\hline $\begin{array}{l}\text { KAGS } \\
\text { (grade) }\end{array}$ & $\begin{array}{l}\text { Myrtle group } \\
N(\%)\end{array}$ & $\begin{array}{l}\text { Control group } \\
N(\%)\end{array}$ & $t$ & $p$ \\
\hline 1 & $5(50)$ & $6(60)$ & 0.130 & 0.722 \\
2 & $3(30)$ & $2(20)$ & & \\
3 & $1(10)$ & $2(20)$ & & \\
4 & $1(10)$ & $0(0)$ & & \\
\hline
\end{tabular}

Table 7 Test of homogeneity for skin condition index

\begin{tabular}{lllll}
\hline & $\begin{array}{l}\text { Myrtle group } \\
M( \pm S D)\end{array}$ & $\begin{array}{l}\text { Control group } \\
M( \pm S D)\end{array}$ & $t$ & $p$ \\
\hline Erythema & $392.50( \pm 62.54)$ & $378.30( \pm 47.86)$ & 0.479 & 0.498 \\
Outstanding pore & $1271.94( \pm 677.33)$ & $1127.65( \pm 905.94)$ & 0.082 & 0.778 \\
Large pore & $38.80( \pm 46.38)$ & $30.86( \pm 53.98)$ & 0.041 & 0.842 \\
Blackhead & $649.16( \pm 468.21)$ & $569.50( \pm 630.08)$ & 0.049 & 0.827 \\
Sebum & $7.57( \pm 2.73)$ & $8.66( \pm 5.44)$ & 2.503 & 0.131 \\
Desquamation & $245.22( \pm 95.22)$ & $232.49( \pm 101.45)$ & 0.124 & 0.729 \\
Microorganism & $8343.90( \pm 3486.55)$ & $7883.30( \pm 2192.81)$ & 1.374 & 0.256 \\
\hline
\end{tabular}

secured the homogeneity in skin condition between the subjects (Table 7).

\section{Effects for treating acne skin Findings based on KAGS}

In terms of changes in the acne grades due to the treatment using myrtle or no such treatment, the average acne grade in the experimental group significantly decreased from grade 1.8 before the treatment to grade 0.9 $(t=5.014, p=0.001)$. In the control group, the average acne grade decreased a little from grade 1.6 to grade 1.5. However, the changes were not statistically significant $(t$ $=0.557, p=0.591$ ). In terms of changes in the acne grades based on the KAGS in each group, the experimental group treated with myrtle, which had consisted of seven persons with grade 1, three persons with grade 2 , one person with grade 3 , and one person with grade 4 before the tests, was found 6 weeks after the tests to consist of three persons with grade 0 , seven persons with grade 1, 0 persons with grade 2 , and one person with grade 3 , showing a statistically significant decrease in acne grades of $80 \%$ of the subjects $(p<0.01)$. The control group with no treatment using myrtle, which had consisted of six persons with grade 1, two persons with grade 2, and two persons with grade 3, was found 6 weeks after the tests to consist of six persons with grade 1 , three persons with grade 2 , and one person with grade 3, showing no particular difference from before the tests. As a result of test of the changes in acne grades between the two groups, it is found there is a statistically significant difference between the two groups with $t=3.151$ and $p=0.006$ (Table 8).

\section{Changes in pore index}

For an analysis of the pore index, the pores on the facial skin of the subjects were divided into outstanding pores, large pores, and blackheads. The outstanding pore index decreased by 364.4 in the experimental group, but increased by 19.2 in the control group. As a result of the test of the changes in the outstanding pores, it is found there is a statistically significant difference between the two groups with $t=4.572$ and $p<0.001$. The large pore 
Table 8 The comparison in the group KAGS N(\%)

\begin{tabular}{|c|c|c|c|c|c|c|c|c|}
\hline \multirow[t]{3}{*}{ KAGS } & \multicolumn{3}{|l|}{ Myrtle } & \multicolumn{3}{|l|}{ Control } & \multirow[t]{3}{*}{$t$} & \multirow[t]{3}{*}{$p$} \\
\hline & \multicolumn{3}{|l|}{ Week } & \multicolumn{3}{|l|}{ Week } & & \\
\hline & 0 & 3 & 6 & 0 & 3 & 6 & & \\
\hline 0 & $0(0)$ & $1(10)$ & $3(30)$ & $0(0)$ & $0(0)$ & $0(0)$ & 3.151 & $0.006^{* *}$ \\
\hline 1 & $5(50)$ & $7(10)$ & $7(30)$ & $6(60)$ & $5(50)$ & $6(60)$ & & \\
\hline 2 & $3(30)$ & $1(70)$ & $0(0)$ & $2(20)$ & $4(40)$ & $3(30)$ & & \\
\hline 3 & $1(10)$ & $1(10)$ & $1(10)$ & $2(20)$ & $1(10)$ & $1(10)$ & & \\
\hline 4 & $1(10)$ & $0(10)$ & $0(0)$ & $0(0)$ & $0(0)$ & $0(0)$ & & \\
\hline$M \pm S D$ & $1.8 \pm 1.0$ & & $0.9 \pm 0.9^{* *}$ & $1.6 \pm 0.8$ & & $1.5 \pm 0.7$ & & \\
\hline
\end{tabular}

$p<0.01$ is present as **

index decreased by 4.3 in the experimental group, but increased by 1.1 in the control group. As a result of test of the changes in the large pores, it is found there is a statistically significant difference between the two groups with $t=3.16$ and $p=0.005$. The blackhead index decreased by 362.0 in the experimental group, but increased by 49.6 in the control group. As a result of test of the changes in the blackhead, it is found there is a statistically significant difference between the two groups with $t=5.130$ and $p<0.001$ (Table 9).

\section{Changes in erythema index}

The erythema index decreased by 27.5 in the experimental group, but increased by 7.8 in the control group. However, as a result of test of the changes, it is found there is no statistically significant difference between the two groups with $t=1.833$ and $p=0.083$ (Table 10).

\section{Changes in sebum index on surface of skin}

The sebum index decreased by 2.4 in the experimental group, but increased by 0.6 in the control group. As a result of test of the changes, it is found there is a statistically significant difference between the two groups with $t=2.313$ and $p=0.033$ (Table 11).

\section{Changes in desquamation index on surface of skin}

The desquamation index decreased by 98.9 in the experimental group, but increased by 35.6 in the control group. As a result of test of the changes, it is found there is a statistically significant difference between the two groups with $t=4.34$ and $p<0.001$ (Table 12). There occurred something noteworthy in the desquamation index in week 3. In view of the statistics in week 3 of the experimental group, it is found there is almost no change in the average and the standard deviation compared to those figures in week 0 , but there is a great difference in the desquamation index between subjects in the experimental group. The subjects in the experimental group were divided into two groups: one with an increased desquamation index in week 3 , which is an early stage of the test, and a remarkably decreased desquamation index in week 6; and the other with a decreased desquamation index both in week 3 and week 6 . However, the division in week 3 disappeared in week 6 , with all

Table 9 The comparison in weekly average of outstanding pores, large pores, and blackheads

\begin{tabular}{|c|c|c|c|c|c|}
\hline & & $\begin{array}{l}\text { Myrtle } \\
M( \pm S D)\end{array}$ & $\begin{array}{l}\text { Control } \\
M( \pm S D)\end{array}$ & t & $p$ \\
\hline \multirow[t]{4}{*}{ Outstanding pores } & 0 week & $1271.9( \pm 677.3)$ & $1127.7( \pm 905.9)$ & 4.572 & $0.000^{* *}$ \\
\hline & 3 week & $1080.8( \pm 586.7)$ & 1132.5( \pm 799.9$)$ & & \\
\hline & 6 week & $907.5( \pm 484.6)$ & $1146.9( \pm 853.8)$ & & \\
\hline & 0-6 gap & $-364.4( \pm 232.2)$ & $+19.2( \pm 128.4)$ & & \\
\hline \multirow[t]{4}{*}{ Large pores } & 0 week & $38.8( \pm 46.4)$ & $30.9( \pm 54)$ & 3.160 & $0.005^{* *}$ \\
\hline & 3 week & $35.1( \pm 44.5)$ & $31.2( \pm 53.5)$ & & \\
\hline & 6 week & $34.5( \pm 43.4)$ & $31.9( \pm 54)$ & & \\
\hline & 0-6 gap & $-4.3( \pm 4.9)$ & $+1.1( \pm 2.3)$ & & \\
\hline \multirow[t]{4}{*}{ Blackheads } & 0 week & $649.2( \pm 468.2)$ & $569.5( \pm 630.1)$ & 5.130 & $0.000^{* *}$ \\
\hline & 3 week & $508.5( \pm 342.4)$ & $629.1( \pm 662.9)$ & & \\
\hline & 6 week & $287.2( \pm 229.8)$ & $619.1( \pm 647.1)$ & & \\
\hline & 0-6 gap & $-362.0( \pm 244.6)$ & $+49.6( \pm 67.6)$ & & \\
\hline
\end{tabular}


Table 10 The comparison in group of erythema

\begin{tabular}{lllll}
\hline & $\begin{array}{l}\text { Myrtle } \\
M( \pm \text { SD })\end{array}$ & $\begin{array}{l}\text { Control } \\
M( \pm \text { SD })\end{array}$ & $t$ & $p$ \\
\hline Week 0 & $392.5( \pm 62.5)$ & $378.3( \pm 47.9)$ & 1.833 & 0.083 \\
Week 3 & $379.5( \pm 57.9)$ & $387.5( \pm 68.3)$ & & \\
Week 6 & $365( \pm 48.4)$ & $386( \pm 68.2)$ & & \\
Gap (week 0-6) & $-27.5( \pm 34.3)$ & $+7.8( \pm 50.2)$ & & \\
\hline
\end{tabular}

subjects in the experimental group having decreased dead skin cells in week 6 .

\section{Changes in microorganism index on surface of skin}

The microorganism index decreased by 3334.5 in the experimental group and decreased by 335.2 in the control group. As a result of the test of the changes in the microorganism index, it is found there is a statistically significant difference between the two groups with $t=$ 2.897 and $p=0.009$ (Table 13).

\section{Discussion}

This study applied myrtle essential oil, which has no irritation, no toxicity, and no sensitivity among natural materials (Lawless 1995), to acne skin to see the effects. As a result of the tests, all of the acne grades, the erythema index, the pore index, the desquamation index, and the microorganism index showed an improvement, with a statistically significant result. An improved acne grade, according to the KAGS criteria, refers to a reduced number of inflammatory acne. In the process of this study's tests, there are two major factors to affect changes in acne grades: the act of pressing out acne; and the application of myrtle substances. However, the act of pressing out acne was equally done to the control group, leading to no great change in the acne grades. Therefore, it can be learned that the myrtle substances have had a direct impact on improving the acne grades, while the act of pressing out acne with no effective substances applied has been found to bring no great improvement.

It can be seen that, by analyzing an improvement of the acne grades based on the mechanism of generation of acne, an improved acne grade results from a combination of removal of dead skin cells and sebum,

Table 11 The comparison in group of sebum

\begin{tabular}{lllll}
\hline & $\begin{array}{l}\text { Myrtle } \\
M( \pm \text { SD) }\end{array}$ & $\begin{array}{l}\text { Control } \\
M( \pm \text { SD })\end{array}$ & $t$ & $p$ \\
\hline Week 0 & $7.6( \pm 2.7)$ & $8.7( \pm 5.4)$ & 2.313 & $0.033^{*}$ \\
Week 3 & $6.7( \pm 2.4)$ & $9.5( \pm 5.4)$ & & \\
Week 6 & $5.2( \pm 2.7)$ & $9.2( \pm 4.3)$ & & \\
Gap (week 0-6) & $-2.4( \pm 2.7)$ & $+0.6( \pm 2.9)$ & & \\
\hline
\end{tabular}

$p<0.05$ is present as *
Table 12 The comparison in group of desquamation

\begin{tabular}{lllll}
\hline & $\begin{array}{l}\text { Myrtle } \\
M( \pm \text { SD })\end{array}$ & $\begin{array}{l}\text { Control } \\
M( \pm \text { SD })\end{array}$ & $t$ & $p$ \\
\hline Week 0 & $245.2( \pm 95.2)$ & $232.5( \pm 101.5)$ & 4.340 & $0.000^{* *}$ \\
Week 3 & $241.9( \pm 97.8)$ & $252.4( \pm 97.5)$ & & \\
Week 6 & $146.3( \pm 75.4)$ & $268.1( \pm 96.1)$ & & \\
Gap (week 0-6) & $-98.9( \pm 91.3)$ & $+35.6( \pm 35.5)$ & & \\
\hline$p<0.01$ is present as ** & &
\end{tabular}

antibacterial activity, anti-inflammatory activity, and soothing activity (Del Rosso et al. 2016). An improved microorganism index can be viewed as a result from anti-bacterial activity by oxide-based 1,8-cineole and mono terpene-based $\alpha$-pinene, and limonene. It has been reported that 1,8-cineole has anti-inflammatory and antibacterial effects by suppressing the pathway of leukotriene B4 and prostaglandin E2 in blood mononuclear cells (Bowles 2000). Merghni et al. have cited that there had been a study reporting that 1,8-cineole has a considerable level of anti-microorganism activity to gram-positive species and gram-negative ones (Merghni et al. 2018). This study also confirmed the antibacterial effects of 1,8-cineole, which is a component of myrtle. In addition, $\alpha$-pinene and limonene interact with the receptor system in energy metabolism in living bodies to suppress oxygen intake and ATP synthesis, also inhibiting enzymatic actions (Hale et al. 2015). Accordingly, an improved microorganism index may be regarded as a result from antibacterial effects of 1,8-cineole, $\alpha$-pinene, and limonene. This study also found out that an improved sebum index results from a lipophagy activity of 1,8-cineole, $\alpha$-pinene, and limonene (Battaglia 1997). A lipophagy dissolves intercellular lipid in dead skin cells, inducing the dead skin cells to fall off. Especially, 1,8-cineole, an oxide substance, can present a synergy effect in removing dead skin cells by dissolving keratin protein (Merghni et al. 2018; Battaglia 1997). With regard to the desquamation index changes, there occurred something noteworthy in week 3 . In view of the statistics of the experimental group in week 3 , there shows almost no change in the average and the standard deviation from those in week 0 . However, there showed great differences in the desquamation index between the

Table 13 The comparison in group of skin microorganism

\begin{tabular}{lllll}
\hline & $\begin{array}{l}\text { Myrtle } \\
M( \pm \text { SD })\end{array}$ & $\begin{array}{l}\text { Control } \\
M( \pm S D)\end{array}$ & $t$ & $p$ \\
\hline Week 0 & $8343.9( \pm 3486.6)$ & $7883.3( \pm 2192.8)$ & 2.897 & $0.009^{* *}$ \\
Week 3 & $6436.2( \pm 2710.4)$ & $7555.7( \pm 2252.9)$ & & \\
Week 6 & $5009.4( \pm 1863.3)$ & $7548.1( \pm 2426)$ & & \\
Gap (week 0-6) & $-3334.5( \pm 2784.6)$ & $-335.2( \pm 1722.8)$ & & \\
\hline$p<0.01$ is present as ** & & &
\end{tabular}


subjects in the experimental group. The subjects in the group were divided into two groups: one with an increased desquamation index in week 3 , which is an early stage of the tests, and a remarkably decreased desquamation index in week 6; and the other with a decreased desquamation index both in week 3 and week 6 . However, the division in week 3 disappeared in week 6 , and all subjects in the experimental group experienced a decrease in dead skin cells. This is considered to show that there is a difference in the desquamation index in the early stage of the tests since the desquamation cycles and the condition of dead skin cells vary from person to person (Kim and Choi 2018). By a morphological observation of the skin when the dead skin cells are removed, edema occurs in the basal layer and the upper layer of the thick skin because of an increase in cell activity including an appearance of vimentin thin filament in fibroblast in the thick skin or vascular endothelial cells (Sandoval et al. 2014). An increased edema and activity in the basal layer and the thick skin may be considered a change in reproduction of the skin according to a healing process for a cut. Accordingly, an increased skin elasticity and tightened pores, which occur after dead skin cells are removed, may be regarded as a result from an increase in activity in the basal layer and the upper layer of the thick skin. The results of the tests of this study also confirmed an improved pore index due to a better desquamation index. In addition, it can be learned that the skin has not been made more sensitive by removing dead skin cells from the results of the erythema index. In view of the results of the erythema index, it can be reconfirmed that myrtle not only has effects for removal of dead skin cells and sebum and convergence but also is a safe substance with skin-soothing effects without making the skin more sensitive. It can be learned that, since myrtle simultaneously contains ester-based myrtenyl acetate, which soothes the skin and recovers the balance in the skin, oxide-based 1,8-cineole with effects for desquamation, convergence, and antibacterial and anti-inflammatory activity, and mono terpene-based $\alpha$-pinene and limonene, it presents excellent effects for improving acne skin by synergy effects between activity substances and soothing substances, also serving as a safe substance with low irritation.

\section{Conclusions}

This study applied myrtle essential oil, which contains ester, oxide, and mono terpene, to acne skin to see changes in the skin. This study made foam cleanser, toner, emulsion, and cream pack with myrtle essential oil added to apply them to the facial skin of the subjects. To precisely check the effects of the myrtle substances, there was only a single difference of the addition or no addition of myrtle between the experimental group and the control group, leaving all other conditions equal.

First, the average acne grade significantly decreased from grade 1.8 to grade 0.9 in the experimental group; but, it showed only a statistically insignificant decrease in the control group from grade 1.6 to grade 1.5.

Second, as a result of analysis of pore index, the outstanding pore index decreased by 364.4 in the experimental group, but increased by 19.2 in the control group; the large pore index decreased by 4.3 in the experimental group, but increased by 1.1 in the control group; and, the blackhead index decreased by 362.0 in the experimental group, but increased by 49.6 in the control group. In summary, all of the three pore indices showed a statistically significant decrease in the experimental group.

Third, the erythema index decreased by 27.5 in the experimental group, but increased by 7.8 in the control group. However, the changes in the erythema index did not show a statistically significant difference between the two groups.

Fourth, the sebum index decreased by 2.4 in the experimental group, but increased by 0.6 in the control group. In addition, the changes in the sebum index showed a statistically significant difference between the two groups.

Fifth, the desquamation index decreased by 98.9 in the experimental group, but increased by 35.6 in the control group. The changes in the desquamation index showed a statistically significant difference between the two groups.

Sixth, the microorganism index decreased by 3334.5 in the experimental group, but decreased by 335.2 in the control group. The changes in the microorganism index showed a statistically significant difference between the two groups.

This study has clinically proved that myrtle essential oil has effects for convergence, reduction of erythema, removal of sebum and dead skin cells, and antibacterial activity in the skin of Korean women. Especially, it is confirmed that myrtle essential oil is a safe effective substance for treating acne with skin-soothing effects from the results of reduced erythema.

\section{Abbreviations \\ DI: Desquamation index; El: Erythema index; KAGS: Korean acne grading system}

Acknowledgements

The authors thank all the study subjects who participated in this work.

Funding

Not applicable.

Availability of data and materials Not applicable. 


\section{Authors' contributions}

KK and SA designed the study. HHJ, SNL, and YSK did all of the research such as the experiments, data collection, and statistical analysis. KK and SA wrote the draft of the manuscript. All authors read and approved the final manuscript.

\section{Ethics approval and consent to participate}

The subjects were informed about all information with regard to the test and took part in the test after signing a written consent according to their will.

All clinical tests for this study have undergone the deliberation of the Institutional Review Boards before starting the tests (NO. 1-70005239-AB-N01-2018-KIDS-AHA043-HR-01).

\section{Consent for publication}

Not applicable.

\section{Competing interests}

Sungkwan An is the co-Editor-in-Chief. There was no funding for this article

The authors declare that they have no competing interests.

\section{Publisher's Note}

Springer Nature remains neutral with regard to jurisdictional claims in published maps and institutional affiliations.

\section{Author details}

'URG Inc. (2F, URG B/D), 28, Yangjaecheon-ro 19-gil, Seocho-gu, Seoul, Republic of Korea. ${ }^{2}$ School of Cosmetology, Kyungbok University, Namyangju-si, Gyeonggi-do, Republic of Korea. ${ }^{3}$ Department of Cosmetology, Kyung-In Women's University, Incheon, Republic of Korea. ${ }^{4}$ Department of Image Industry, Graduate School of Engineering, Konkuk University, Seoul, Republic of Korea. ${ }^{5}$ Department of Cosmetics Engineering, Konkuk University, 120 Neungdong-ro, Gwangjin-gu, Seoul 05029, Republic of Korea.

Received: 22 August 2018 Accepted: 14 November 2018

Published online: 10 December 2018

\section{References}

Aleksic V, Knezevic P. Antimicrobial and antioxidative activity of extracts and essential oils of Myrtuscommunis L. Microbiol Res. 2014;169:240-54.

Battaglia S. The complete guide to aromatherapy. Australia: the perfect potion; 1997.

Boni R, Nehrhoff B. Treatment of gram-negative folliculitis in patients with acne. Am J Clin Dermatol. 2003:4:273-6.

Bowles JE. The chemistry of aromatherapeutic oils. 3rd ed. Australia: Allen \& Unwin; 2000.

Del Rosso JQ, Silverberg N, Zeichner JA. When acne is not acne. Dermatol Clin. 2016;34:225-8

Ghasemi E, Raofie F, Najafi NM. Application of response surface methodology and central composite design for the optimisation of supercritical fluid extraction of essential oils from Myrtus communis L. leaves. Food Chem. 2011; 126:1449-53.

Hale SE, Endo S, Arp HPH, Zimmerman AR, Cornelissen G. Sorption of the monoterpenes a-pinene and limonene to carbonaceous geosorbents including biochar. Chemosphere. 2015;119:881-8.

Khunger N, Khunger N, IADVL TF. Standard guidelines of care for chemical peels. Indian J Dermatol Venereol Leprol. 2008:74(Suppl):S5-12.

Kim HS, Choi YH. Comparative study on changes in skin condition according to peeling care techniques. Asian J Beauty Cosmetol. 2018;16:82-92.

Lawless J. The encyclopedia of essential oils: the complete guide to the use of aromatic oils in aromatherapy, herbalism, health, and well being. London: Conari Press; 1995

Li H, Zhao M, Shi Y, Xing Z, Li Y, Wang S, Ying J, Zhang M, Sun J. The effectiveness of aromatherapy and massage on stress management in nurses: a systematic review. J Clin Nurs. 2018. https://doi.org/10.1111/ jocn.14596.

Merghni A, Noumi E, Hadded O, Dridi N, Panwar H, Ceylan O, Mastouri M, Snoussi M. Assessment of the antibiofilm and antiquorum sensing activities of Eucalyptus globulus essential oil and its main component 1,8-cineole against methicillin-resistant Staphylococcus aureus strains. Microb Pathog. 2018:118:74-80.

Momin S, Peterson A, Rosso JQ. A status report on drug-associated acne and acneiform eruptions. J Drugs Dermatol. 2010:9:627-36.

Sandoval LF, Hartel JK, Feldman SR. Current and future evidence-based acne treatment: a review. Expert Opin Pharmacother. 2014;15:173-92.

Yang YC, Lee HS, Clark JM, Ahn YJ. Insecticidal activity of plant essential oils against Pediculus humanus capitis (Anoplura: Pediculidae). J Med Entomol. 2004:41:699-704.

\section{Ready to submit your research? Choose BMC and benefit from:}

- fast, convenient online submission

- thorough peer review by experienced researchers in your field

- rapid publication on acceptance

- support for research data, including large and complex data types

- gold Open Access which fosters wider collaboration and increased citations

- maximum visibility for your research: over $100 \mathrm{M}$ website views per year

At BMC, research is always in progress.

Learn more biomedcentral.com/submissions 